\title{
ANALIZA UČINKA RADA BAGERA PRIMJENOM METODE KRONOMETRAŽE
}

\section{ANALYSIS OF EXCAVATOR WORK EFFICIENCY BY APPYLING CHRONOMETRY METHOD}

\author{
Ana Berljafa*, Ivan Marović ${ }^{* *}$, Diana Car-Pušić ${ }^{* *}$
}

\begin{abstract}
Sažetak
Problemi koje unutar područja organizacije proizvodnje rješava znanstvena disciplina studija rada počeli su se na našim prostorima sustavno rješavati 1960tih godina, a razvoj metoda koje se pritom koriste (npr. kronometraže) traje i danas. Značaj studije rada jest nastojanje racionalizacije organiziranja rada kroz definiranje i praćenje sastavnih elemenata vremena rada s ciljem utvrđivanja normativa koji će vrijediti za radnu operaciju u cjelini. Izračunavanje praktičnih učinaka građevinske mehanizacije je od velike važnosti za utvrđivanje što realnijeg trajanja strojnog rada na gradilištu, a time i veće točnosti predviđanja trajanja cjelokupnog građevinskog projekta. Okosnica ovoga rada je studija i analiza vremena jednog standardnog cikličkog građevinskog stroja u svom jednom tehnološkom postupku. Pritom se promatrala i analizirala radna operacija utovara bagerom u transportno sredstvo. Korištena je povratna metoda kronometraže kojom su se prikupljali podaci na gradilištu s ciljem normiranja rada odnosno utvrđivanja stvarnog učinka rada bagera pri utovaru. Podaci dobiveni mjerenjem su analizirani te je izračunato stvarno vrijeme definiranog tehnološkog postupka i njemu pripadajući normativ. Također, izvršila se usporedba s proračunom praktičnog učinka strojnog rada koji je izračunat pomoću normiranih tablica za proračun učinka standardnog cikličkog građevinskog stroja. Usporedbom su utvrđena odstupanja između izračuna temeljenih na mjerenim podacima i izračunima temeljenim na postojećim tablicama za izračun praktičnog učinka stroja. Analizirana su utvrđena odstupanja kao i razlozi njihova nastanka te su doneseni zaključci s preporukama za ažuriranje postojećih proračunskih tablica.
\end{abstract}

Ključne riječi: bager, metoda kronometraže, mjerenje, studij rada, učinak

\footnotetext{
*Građevinski fakultet, Radmile Matejčić 3, 51000 Rijeka E-mail: ana.berljafa@student.uniri.hr

${ }^{* *}$ Građevinski fakultet, Radmile Matejčić 3, 51000 Rijeka

E-mail: \{ivan.marovic, diana.car.pusic\}@gradri.uniri.hr
} 


\begin{abstract}
Problems within the area of production organization, which are solved by scientific discipline of the work-study, have begun to be systematically dealt with in our region during 1960s, and method development (such as chronometry) persists today. The significance of the work-study is the attempt to rationalize the work organization through the definition and monitoring of the constituent elements of working time with the aim of establishing the norms that will be valid for the work operation as a whole. The calculation of construction machinery practical effect is of great importance for determining the more realistic duration of machine work on construction site, and thus the more accurate prediction of the whole construction project duration. The main topic of this paper is the time study analysis of a standard cyclic construction machine in its one technological process. At the same time, the work operation of the excavator loading into transportation vehicle has been observed and analyzed. Data were obtained by snapback chronometry method with the purpose of determining work efficiency i.e. defining the actual excavator work efficiency during the operation of loading. The data obtained by measurement were analyzed and the actual time of defined technological process was calculated as well as a corresponding normative. Moreover, a comparison was made with the calculation of excavator practical effect, which was calculated using the standardized tables for the calculation of standard cyclic construction machine. The comparison resulted in differences between these two approaches. The identified deviations were analyzed as well as the reasons for their occurrence and conclusions were drawn resulting in recommendations for updating the existing standardized tables for the calculation.
\end{abstract}

Key words: excavator, chronometry method, measurement, work-study, efficiency

\title{
1. Uvod
}

Svakodnevno svjedočimo rastu i dominaciji automatizacije, sve novijih generacija elektroničkih računala i elektroničke obrade podataka te uvođenja robota u područje graditeljstva [1] za obavljanje poslova koje je do sada obavljao čovjek. Predviđa se [2] da će do 2020. na tržištu rada poslove obavljati 1,7 milijun novih industrijskih robota $\mathrm{s}$ prosječnim godišnjim povećanjem njihova broja od $15 \%$. Navedeno predviđanje se isključivo odnosi na područje industrijske proizvodnje, no za očekivati je da će se i u ostalim proizvodnjama na otvorenom, odnosno građenju na gradilištima značajno povećati broj robota i učestalost njihova korištenja.

Ukoliko se proizvodni proces graditeljstva usporedi s industrijskom proizvodnjom, može se zaključiti da se radi o specifičnom obliku proizvodnje koju karakteriziraju sljedeće specifičnosti [3]:

- proizvod je nepomičan dok su proizvodni čimbenici (rad i tehnologije) pomični, 
- rad se obavlja na otvorenom prostoru (utjecaj vremenskih prilika i klime, sezonski karakter proizvodnje i dr.),

- pojedinačnost proizvodnje i dr.

Pritom se rad definira [4] kao „svjesno organizirana, svrsishodna djelatnost ljudi radi postizanja nekog korisnog učinka koja zadovoljava određenu pojedinačnu ili društvenu potrebu“. No, da bi se rad organizirao, potrebno ga je na neki način podijeliti i usustaviti $[5,6]$. Te dijelove nazivamo radnim procesima, a razlikuju se po opisu, izvršiteljima, mjestu rada, primjeni ručnih alata i strojeva i dr. Bez obzira radi li se o ručnom, strojno-ručnom ili strojnom radu, svaki je rad povezan s čovjekom. Klepac [7] navodi kako se radni proces u građevinarstvu općenito definira kao „dio ukupnog rada na građevini kojim se izvodi neka cjelina ili dio građevine, a izvršavaju ga organizirane radne grupe stalnog sastava koje po potrebi mijenjaju alate i koriste se različitim materijalima". Radujković i dr. [6] naglašavaju da je upravo stalnost sastava jednom uspostavljene radne grupe u nekom radnom procesu na nekom gradilištu važan podatak te predstavlja uporište za organizaciju tog dijela rada u analizama i proračunima.

Stoga je važno razumijevati rad i njegovu podjelu na složene radne procese, radne procese, radne operacije, radne postupke i radne pokrete. Ranija istraživanja [7] navode da se kod organizacije većine građevinskih procesa koriste samo prve tri navedene razine, naročito ukoliko se radi o građevinskim radovima koji se masovno ponavljaju jer samo takav rad ima smisla proučavati, optimizirati i organizirati.

Utvrđivanje što realnijih praktičnih učinaka standardne građevinske mehanizacije i njihovih normativa rada jedan je od ključnih preduvjeta planiranja strojnog rada na gradilištu [8]. Car-Pušić i dr. [8] utvrdili su postojanje razlika između učinaka dobivenih u fazi planiranja i onih dobivenih mjerenjem na terenu te pokazali da problem proizlazi iz normiranih vrijednosti koeficijenata [9-12] vezanih uz organizacijske uvjete. Daljnja istraživanja $[13,14]$ u kojima je primijenjena metoda kronometraže potvrdila su da je mjerni učinak strojeva u odnosu na planirani učinak veći i do $30 \%$.

Pritom se odnos između praktičnog učinka $\left(U_{P}\right)$, mjerenog učinka $\left(U_{M}\right)$ i teoretskog učinka $\left(\mathrm{U}_{\mathrm{T}}\right)$ promatra kao $\mathrm{U}_{\mathrm{P}} \leq \mathrm{U}_{\mathrm{M}}<\mathrm{U}_{\mathrm{T}}$ iako se u građevinskoj praksi taj odnos ponekad promijeni $u U_{M} \leq U_{P}<U_{T}$.

Stoga su, uz propitivanje navedenog odnosa, glavni ciljevi ovoga rada utvrđivanje postojanja odstupanja između normativa rada dobivenog mjerenjem na terenu i onog dobivenog proračunom putem normiranih vrijednosti te koliko odstupanje iznosi za promatrani radni proces. U slučaju 
značajnih odstupanja cilj je utvrditi razloge njihova nastajanja s obzirom na koeficijente redukcije iz postojećih proračunskih tablica.

\section{Pregled područja studija rada}

Proučavanje elemenata i metoda rada sastavni je dio svih organizacijskih teorija, pri čemu se u fokus uvijek stavlja učinkovitost i sigurnost pri radu, uz racionalizaciju pokreta, tj. ergonomiju, što u svom krajnjem obliku dovodi do humanizacije rada. Pritom treba imati u vidu da se rad strogo promatra s aspekta ograničenih postojećih resursa i racionalnog korištenja svih oblika energije.

Pristupi proučavanju elemenata i metoda rada temelje se na raščlanjivanjima složenog rada na jednostavne dijelove koji se mogu lakše razumjeti, opisati i organizirati, a povezani su s teoretičarima razvoja klasične teorije organizacije krajem 19. stoljeća koja se razvijala u tri glavna smjera [6]:

- znanstveni pristup upravljanju koji je razvijao Frederick W. Taylor,

- administrativna teorija upravljanja Henryja Fayola,

- model birokratske organizacije Maxa Webera.

Za razliku od navedenih, na građevinarstvo su poseban utjecaj imala proučavanja Granta i bračnog para Gilbreth [6, 7], čija su istraživanja vezana uz povećanje učinkovitosti radu pritom analizirajući pokrete pri radu (engl. Motion Study). Sustavni pristup studiji vremena postavio je Taylor u svom djelu [15] u kojem je postavio četiri bitne odrednice studije vremena i studije pokreta (engl. Time and Motion Study) čiji se principi primjenjuju i danas. Taylorove postavke mogu se sažeti na sljedeće:

- istražiti najbolji način rada,

- za postizanje uspjeha u radu potrebno je proučavati vrijeme da bi se izvršitelju rada mogle dati jasne upute,

- grubo mjerenje vremena zamijeniti što preciznijim,

- istražiti gubitke vremena te opravdane priznati.

Studija rada može se definirati kao disciplina unutar područja organizacije proizvodnje čiji je zadatak da se znanstvenim metodama, logički, cjelovitim i sustavnim analizama nekog prethodno definiranog rada dođe do optimalnog oblikovanja načina rada te realno potrebnog vremena izrade. Taboršak [5] navodi da se pritom utvrđivanje optimalno oblikovanog načina rada odnosi na prilagođavanje radnog mjesta, metoda i uvjeta rada, dok nam utvrđivanje realno potrebnog vremena izrade služi za 
ispravno izračunavanje norme koja prema svojoj definiciji predstavlja „organizacijsko mjerilo humano oblikovanog rada“.

Rezultati aktivnog provođenja studija rada su mnogobrojni te su izraženi ne samo u povećanju proizvodnje i smanjivanju gubitaka već i u smanjenju troškova poslovanja. Pritom se metode studija rada mogu primijeniti ne samo u proizvodnji i radnim mjestima neposrednih izvršilaca, već i u svim djelatnostima kao i na radnim mjestima posrednih izvršilaca rada. Nastoji li se problem povećanja proizvodnosti i smanjivanja troškova, uz optimalnu kvalitetu i humaniji način rada, rješavati boljom organizacijom i promišljenijim radom koristeći vlastita sredstva, onda će studija rada mnogo pomoći. U protivnom, stvorit će se baza velike količine neobrađenih podataka koje je potrebno arhivirati.

Metode studije rada pružaju mogućnost analize svakog rada, kao i čitave proizvodnje, a poslije analize daju i mogućnosti za poboljšanje postojećeg načina rada te određivanje optimalnog vremena izrade, koje je temelj za ispravno izračunavanje normativa rada [5].

Iz sheme studija rada (Slika 1) može se vidjeti da je za ostvarenje zadataka, ciljeva i svrhe studija rada potrebno obuhvatiti studij i analizu vremena kao i pojednostavljenje rada. Cilj provođenja studija i analize vremena jest da se znanstvenim metodama utvrdi, analizira i izračuna vrijeme izrade i normativ rada koji služe kao organizacijsko mjerilo. Pojednostavljenje rada ili racionalizacija rada ima za cilj da se analizom utvrdi odvijanje rada, tj. tehnološkog procesa kako bi se radno mjesto i uvjeti rada optimalno oblikovali te bili prilagođeni ergonomiji provođenja procesa. 


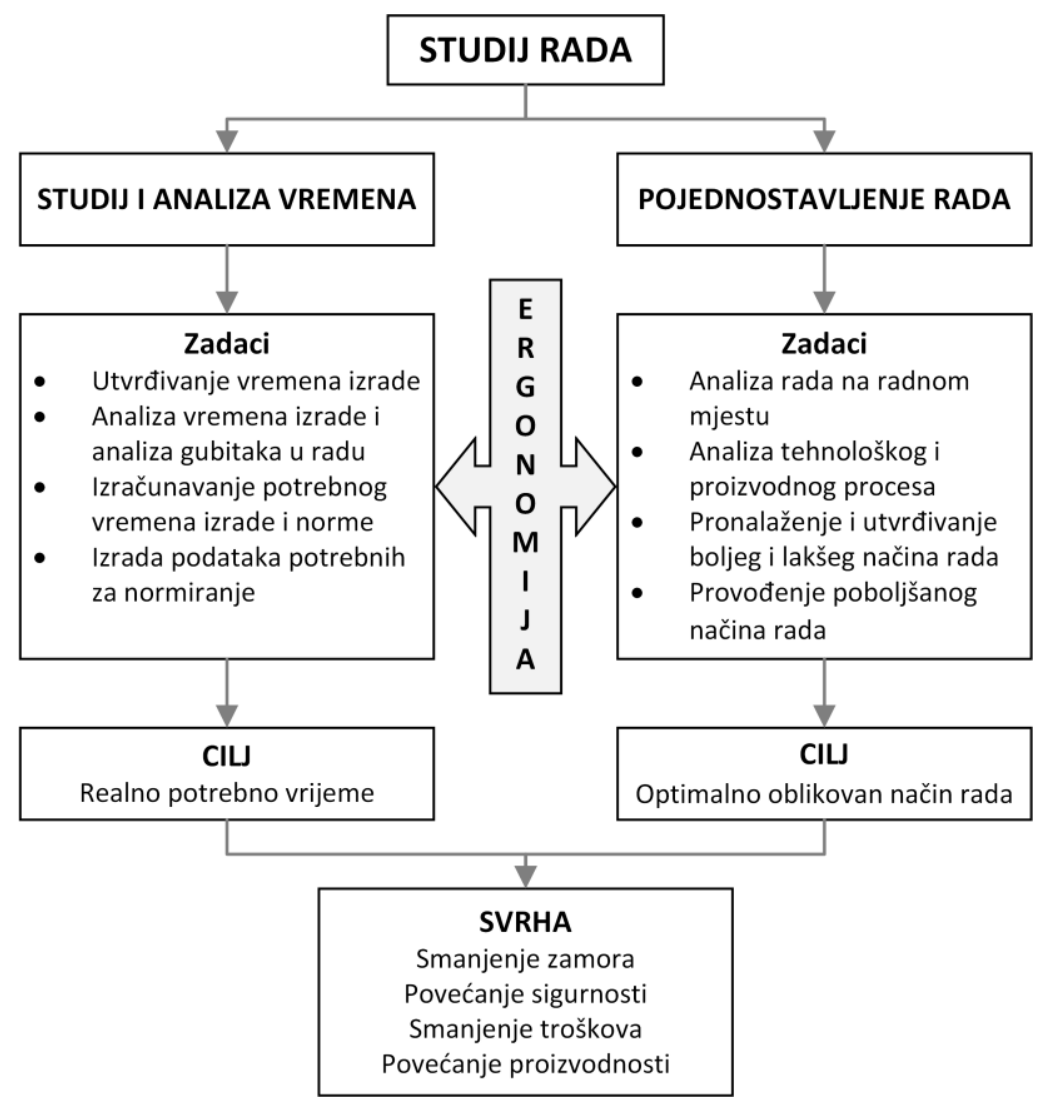

Slika 1. Shema studija rada (oblikovano prema [5])

Glavni doprinos studija rada leži u racionalizaciji organiziranja rada na radnom mjestu i određivanju realnih vremenskih normativa, a sve s ciljem povećanja proizvodnosti rada i smanjenjem troškova uz naglasak na ergonomiji rada radnika te smanjenju njegova zamora uz istovremeno povećanje sigurnosti rada. Važno je napomenuti da se tek na optimalno oblikovanom radnom mjestu mogu dobiti realni vremenski normativi.

\subsection{Sastavni elementi vremena rada}

Ukupno vrijeme rada koje je potrebno da se izvede neki posao zadanim radnim nalogom sastoji se od slijedećih elemenata [5]:

- pripremno-završno vrijeme (potrebno je za pripremanje radnog mjesta za neki posao te uređenje tog mjesta nakon rada), 
- tehnološko vrijeme (označava ono vrijeme koje je potrebno za izvršavanje nekog efektivnog rada, bez obzira obavlja li se rad ručno ili strojem),

- pomoćno vrijeme (ono vrijeme koje je potrebno za obavljanje pomoćnih poslova koji omogućavaju izvođenje tehnoloških),

- dodatno vrijeme (služi za kompenzaciju onih gubitaka vremena koje ima radnik tijekom dana, a nije ih sam prouzročio).

Navedeni elementi vremena rada nalaze se u svakom tehnološkom i radnom procesu te se iskazuju u postotcima vremena izrade. Budući da postoje razni uzroci opravdanih gubitaka u radu koji se moraju obuhvatiti normativom, oni se pomoću stalnih i promjenjivih koeficijenata iskazuju unutar elementa "dodatno vrijeme".

Koeficijent zamora i koeficijent djelovanja okoline nazivaju se stalnim koeficijentima jer isključivo ovise o vrsti rada i okolini u kojoj se taj rad obavlja te o utrošku energije ljudskog organizma za dotični posao. S druge strane, promjenjivim se označava dopunski koeficijent (dopunski koeficijent za propisani odmor, fiziološke potrebe i organizacijske gubitke) koji se za svako radno mjesto i radni proces mora posebno odrediti i periodički kontrolirati.

Procjena zalaganja jest važan element koji je potrebno promatrati i ocijeniti prilikom ručnog ili strojno-ručnog rada. Iako su se različiti analitičari vremena tijekom povijesti bavili zalaganjem radnika i procjenom zalaganja, generalno se razlozi potrebe za primjenom procjene zalaganja prilikom snimanja vremena mogu oblikovati na slijedeći način:

- dva radnika nikada ne mogu izvoditi rad jednakom brzinom bez međusobnog usklađivanja;

- potrebno je otkloniti utjecaj radnikove promjene zalaganja nastao za vrijeme snimanja vremena.

Može se postaviti pitanje treba li snimati vrijeme rada bržeg ili sporijeg radnika, tj. koje od njihovih izmjerenih vremena rada uzeti kao osnovicu za izračunavanje normativa vremena promatranog radnog procesa.

\subsection{Načini određivanja vremena izrade}

Kroz povijest su se razvijali brojni načini određivanja vremena izrade, odnosno rada $[5,6,7]$, od kojih svaki ima svoje prednosti i mane bez obzira primjenjuje li se u određivanju vremena ručnog, strojno-ručnog ili strojnog rada. Stoga je preporučljivo da se pri donošenju odluke o izboru načina određivanje vremena izrade odabrati onaj način koji je najekonomičniji. 
Općenito, načini određivanja vremena izrade mogu se podijeliti na procjenu, snimanje, izraze za strojni rad te sisteme unaprijed određenih vremena. Od navedenih načina, najstarija, najpoznatija i najraširenija metoda određivanja vremena izrade po sastavnim elementima vremena je snimanje vremena kronometrom. Zbog svoje se praktičnosti i danas često koristi na gradilištima prilikom praćenja i kontrole izvršavanja građevinskih projekata.

\section{Metodologija provođenja istraživanja}

Provedeno istraživanje može se podijeliti na dva dijela: istraživanje za stolom te istraživanje na terenu. Početak istraživanja započinje definiranjem predmeta istraživanja kojim se stvaraju preduvjeti za provođenje teorijskih i terenskih istraživanja. Nakon definiranja tehnološkog procesa koji se namjerava pratiti, snimati i analizirati, potrebno je odabrati metodu snimanja te prikupljene podatke statistički obraditi (proces prikazan u poglavlju 3.1) kako bi se utvrdio normativ strojnog rada. Na temelju prikupljenih podataka o uvjetima na lokaciji proračunava se normativ strojnog rada putem postojećih normiranih tablica. Dobiveni rezultati dvaju pristupa se uspoređuju te analiziraju kako bi se utvrdilo odstupanje između dviju metodologija proračuna strojnih učinaka.

\subsection{Metode snimanja pomoću kronometra}

Metoda snimanja vremena kronometrom ili metoda kronometraže se, uz sami mjerni instrument (kronometar, tj. štoperica), u svojoj osnovi oslanja na matematičku statistiku i teoriju vjerojatnosti. Kod ove metode snimanja snima se koristan rad prethodno definiranog radnog procesa koji je podijeljen na radne operacije.

U graditeljstvu ova metoda se najčešće primjenjuje kod snimanja kratkih cikličkih procesa koji se na gradilištima u pravilu javljaju kod standardnih građevinskih strojeva (npr. bagera, dozera, utovarivača, skrejpera, grejdera, valjaka) te transportnih sredstava, poput vozila i dizala.

Pritom su razvijene dvije metode snimanja pomoću kronometra $[5,15]$ :

- protočna metoda očitavanja vremena - tijekom mjerenja radnog procesa se neprekidno očitava stanje na kronometru,

- povratna metoda očitavanja vremena - tijekom mjerenja radnog procesa stanje na kronometru se bilježi i resetira nakon svake radne operacije. 
Budući da se prilikom snimanja radnog procesa unaprijed ne poznaje vrijeme trajanja ciklusa ili slučajna varijabla $X$ osnovnog skupa, uobičajeno je da se provodi snimanje radnih vremena koje radnik ili stroj utroši za obavljanje pojedinačnih radnih operacija u proizvodnom tehnološkom procesu. Stoga se slučajna varijabla pokorava normalnoj razdiobi te je potrebno utvrditi intervalnu procjenu očekivanja.

Izetbegović i Žerjav [16] navode kako se u stvarnoj primjeni u građevinarstvu u izrazima za intervalne procjene očekivanja umjesto procjene standardne devijacije aritmetičke sredine uzorka preporuča koristiti standardna greška uzorka pomoću izraza:

- za veliki uzorak $(\mathrm{n} \geq 31)$ :

$\bar{X}_{n}-u * s_{n}<\mu<\bar{X}_{n}+u * s_{n}$,

- za mali uzorak $(\mathrm{n}<31)$ :

$\bar{X}_{n}-t_{o} * s_{n}<\mu<\bar{X}_{n}+t_{o} * s_{n}$,

gdje se standardna greška snimljenog uzorka izračunava preko izraza:

$$
s_{n}=\sqrt{\frac{\sum_{i=1}^{n}\left(X_{i}-\bar{X}_{n}\right)^{2}}{n-1}} .
$$

Neposrednim izračunom u obrascu metode kronometraže najprije se izračuna snimljeni normativ vremenskog trajanja radnog procesa $\left(\mathrm{N}_{\mathrm{VS}}\right)$ prema izrazu:

$$
N_{V S}=\sum_{j=1}^{m}\left(\bar{X}_{n} * k_{P Z}\right)
$$

gdje su:

$\bar{X}_{n}$ prosječno vrijeme radne operacije i $(1,2, \ldots \mathrm{n})$,

$m$ ukupni broj zahvata u radnom ciklusu, a

$k_{P Z}$ koeficijent zalaganja izvršitelja.

Budući da se metodom kronometraže snimanje vrši u relativno kratkom vremenu u odnosu na vremensko trajanje cijele radne smjene, stvarni normativ vremena $\left(\mathrm{N}_{\mathrm{V}}\right)$ dobit će se tek nakon što se snimljeni normativ korigira uz pomoć ukupnog dodatnog koeficijenta vremena [16]:

$$
N_{V}=N_{V S} * K_{D},
$$

Ukupni dodatni koeficijent vremena dobije se prema izrazu:

$$
K_{D}=1+k_{a} * k_{n}+k_{d} \text {. }
$$


Pritom se koeficijent djelovanja okoline (ka) i koeficijent zamora (kn) mogu iščitati iz tablica [5], dok se dopunski koeficijent (kd) izračunava preko elemenata vremena rada ( $t_{P}$ - pripremno-završno vrijeme u radnoj smjeni, $t_{N}$ - planirani tehnološki zastoji u radnoj smjeni i $t_{E}-$ fiziološke potrebe i kratki odmori u radnoj smjeni) iz izraza:

$$
k_{d}=\left(t_{P} * t_{N}+t_{E}\right) / 100 \text {. }
$$

Provođenjem navedeno postupka dobiva se stvarni normativ vremena rada promatranog stroja tijekom definiranog radnog procesa koji je $u$ recipročnom odnosu s učinkom istog.

\section{Rezultati i diskusija}

\subsection{Uvjeti na lokaciji i definiranje tehnološkog procesa}

Terenska mjerenja [17] strojnog učinka (tehnološki, tj. radni proces utovara iskopanog materijala bagerom u transportno sredstvo) napravljena su na gradilištu KBC Sušak u Rijeci u periodu od 18.4. do 13.6.2017. godine. Za snimanje je odabran bager gusjeničar CAT 330F opremljen dubinskom lopatom zapremine $1,75 \mathrm{~m}^{3}$ kojim je minirani materijal (pretežno IV kategorija) utovarivan $\mathrm{u}$ transportna sredstva. Tijekom snimanja kronometrom korištena je i vizualna metoda kojom je, uzimajući u obzir rastresitost materijala $\left(\mathrm{k}_{\mathrm{r}}=1,35\right)$, procjenjivana ispunjenost dubinske lopate pri zahvatu materijala [17].

Promatrani radni proces je podijeljen na četiri radne operacije (Tablica 1). Svaka pojedina radna operacija mjerila se povratnom metodom kronometraže s ciljem dobivanja stvarnog normativa vremena radnog procesa "utovar iskopanog materijala bagerom u transportno sredstvo“.

Tablica 1. Podjela promatranog radnog procesa na radne operacije

\begin{tabular}{|c|c|c|}
\hline $\begin{array}{c}\text { R. } \\
\text { br. }\end{array}$ & Naziv radne operacije & Oznaka \\
\hline 1. & Zahvat materijala dubinskom lopatom bagera & 01 \\
\hline 2. & Rotacija ruke bagera u položaj iznad transportnog sredstva & 02 \\
\hline 3. & Ispuštanje materijala iz dubinske lopate bagera u \\
transportno sredstvo & 03 \\
\hline 4. & $\begin{array}{c}\text { Rotacija ruke bagera u početni položaj i priprema za } \\
\text { ponovni zahvat materijala }\end{array}$ & 04 \\
\hline
\end{tabular}


Prilikom promatranog radnog procesa rotacija ruke bagera u radnim operacijama 02 i 04 iznosi $180^{\circ}$.

\subsection{Rezultati terenskih mjerenja i izrada normativa}

Ukupno je izmjereno 665 radnih operacija navedenog radnog procesa podijeljenih između 159 potpunih radnih ciklusa i 14 djelomičnih. Pod potpunim radnim ciklusom podrazumijeva se radni proces (RP) utovara iskopanog materijala bagerom $\mathrm{u}$ transportno sredstvo kod kojeg su izmjerene vrijednosti svih prethodno utvrđenih radnih operacija (01-04), dok se pod djelomičnim radnim ciklusom podrazumijeva tehnološki proces bez snimljene radne operacije 01 . U daljnju statističku obradu uključeni su isključivo potpuno snimljeni radni ciklusi.

U Tablici 2 prikazani su statistički podaci provedenih mjerenja tehnološkog procesa te prikaz izračuna snimljenog vremenskog trajanja radnog ciklusa.

Tablica 2. Statistika provedenih terenskih mjerenja

\begin{tabular}{|c|c|c|c|c|c|c|c|}
\hline $\mathbf{R P}$ & $\mathbf{X}_{\max }$ & $\mathbf{X}_{\min }$ & $\boldsymbol{\Sigma x}(\mathbf{s e c})$ & $\mathbf{\Sigma x}(\mathbf{\%})$ & $\overline{\boldsymbol{x}}$ & $\mathbf{k P Z}$ & $\mathbf{N}$ vs \\
\hline 01 & 21,00 & 1,80 & $1.138,50$ & 28,81 & 7,16 & 1,02 & 7,30 \\
\hline 02 & 15,40 & 1,50 & 873,10 & 22,09 & 5,49 & 1,00 & 5,49 \\
\hline 03 & 18,00 & 2,70 & 767,10 & 19,41 & 4,82 & 1,00 & 4,82 \\
\hline 04 & 62,90 & 2,10 & $1.173,20$ & 29,69 & 7,37 & 0,97 & 7,15 \\
\hline $\boldsymbol{\Sigma}$ & & & $\mathbf{3 . 9 5 1 , 9 0}$ & & $\mathbf{2 4 , 8 4}$ & & $\mathbf{2 4 , 7 6}$ \\
\hline
\end{tabular}

Dobiveni normativ snimljenog vremenskog trajanja radnog procesa $\left(\mathrm{N}_{\mathrm{VS}}\right)$ iznosi 24,76 sekundi, a potrebno ga je korigirati ukupnim dodatnim koeficijenom vremena prema izrazu (6), dok se pritom iz tablice [5], sukladno uvjetima snimanog tehnološkog procesa, može uzeti vrijednost 2,035 za koeficijent $K_{D}$.

Uvođenjem svih navedenih vrijednosti u izraz (5) izračun stvarnog normativa vremena $\left(\mathrm{N}_{\mathrm{V}}\right)$ iznosi 50,3866 sekundi. Navedeno vrijeme predstavlja stvarni normativ vremena po jednom ciklusu rada, tj. radnom procesu, što u satima predstavlja ukupno vrijeme od 0,0140 h/ciklusu.

Kontinuiranim promatranjem rada strojara uvidio se problem ujednačenog ispunjenja lopate prilikom radne operacije 01. Unatoč njegovom dobrom zalaganju pri radu (opisano koeficijentom zalaganja u Tablici 2), tijekom svakog radnog ciklusa ne izvrši se utovar jednake 
količine materijala u transportno sredstvo zato što se količina zahvaćenog materijala u lopati razlikuje od zahvata do zahvata. Stoga se pristupilo praćenju ukupnog vremena pri utovaru jednog transportnog sredstva i procjeni ispunjenosti dubinske lopate pri tom radnom procesu. Pritom je korištena metoda promatranja [18] kojom je procijenjeno da je pri radnim ciklusima dubinska lopata u prosjeku napunjena oko 75\% (materijali iz iskopa razlikuju se po rastresitosti, a time i količini punjenja lopate bagera). Navedena vrijednost poslužila je za korekciju zapremine, tj. za preciznije oblikovanje stvarnog normativa vremena.

Ovim pristupom se utvrdilo da je prosječno pri svakom ciklusu utovareno $1,3125 \mathrm{~m}^{3}$ materijala, što znači da stvarni normativ vremena $\left(\mathrm{N}_{\mathrm{v}}\right)$ promatranog rada bagera pri utovaru iskopanog materijala u transportno sredstvo na predmetnom gradilištu iznosi $0,0184 \mathrm{~h} / \mathrm{m}^{3}$.

\subsection{Rezultati proračuna normativa putem normiranih vrijednosti}

Proračun praktičnog učinka bagera izrađen je na temelju već opisanih informacija (vidi poglavlje 4.1) koje su poslužile za izbor koeficijenata iz normiranih tablica [9-12]. Poznato je da se praktični učinak ( $\left.U_{P}\right)$ građevinskog stroja proračunava na način da se njegov teoretski učinak (kvocijent zapremine radnog tijela stroja i vremena jediničnog radnog ciklusa) pomnoži s koeficijentom redukcije (redukcijski koeficijent materijala, uvjeta rada i organizacije rada) prema izrazu:

$$
U_{P}=\frac{q * T}{t_{c}} * k_{R},
$$

dok se koeficijent redukcije izračunava prema izrazu:

$$
k_{R}=k_{A} * k_{B} * k_{C} \text {. }
$$

Također, iz navedenih normiranih tablica za rotaciju ruke bagera od $180^{\circ}$ odabrano je vrijeme jediničnog radnog ciklusa od 25 sekunde. Linarić $[9,19]$ navodi da bi navedene normirane tablice trebalo preispitati zbog starosti podataka te predlaže da se koriste vrijednosti radnog ciklusa iz priručnika tvrtke Caterpillar (noviji strojevi). Prema tom priručniku, odabrano vrijeme jediničnog radnog ciklusa iznosi 20 sekundi te je napravljen kontrolni proračun, dok su u Tablici 3 prikazane odabrane vrijednosti koeficijenata redukcije te njihovi nazivi. 
Tablica 3. Koeficijenti redukcije teoretskog učinka

\begin{tabular}{|c|c|}
\hline Naziv koeficijenta redukcije & Vrijednost [-] \\
\hline $\mathrm{k}_{\mathrm{A}}-$ koeficijent materijala & $=\mathrm{k}_{\mathrm{p}} * \mathrm{k}_{\mathrm{r}} * \mathrm{k}_{\mathrm{vm}}$ \\
\hline $\mathrm{k}_{\mathrm{p}}$ - koeficijent punjenja lopate bagera & 1,00 \\
\hline $\mathrm{k}_{\mathrm{r}}$ - koeficijent rastresitosti materijala & 0,74 \\
\hline $\mathrm{k}_{\mathrm{vm}}$ - koefcijent vlažnosti materijala & 0,95 \\
\hline $\mathrm{k}_{\mathrm{B}}-$ koeficijent uvjeta rada & $=\mathrm{k}_{\mathrm{rp}} * \mathrm{k}_{\mathrm{o}} * \mathrm{k}_{\mathrm{u}}$ \\
\hline $\mathrm{k}_{\mathrm{rp}}$ - koeficijent radnog prostora & 1,00 \\
\hline $\mathrm{k}_{\mathrm{o}}$ - koeficijent okretanja ruke bagera & 0,71 \\
\hline $\mathrm{k}_{\mathrm{u}}-$ koeficijent utovara & 0,90 \\
\hline $\mathrm{k}_{\mathrm{c}}$ - koeficijent organizacije rada & $=\mathrm{k}_{\mathrm{og}}{ }^{*} \mathrm{k}_{\mathrm{rv}} * \mathrm{k}_{\mathrm{ds}}$ \\
\hline kog - koeficijent organizacije & 0,80 \\
\hline $\mathrm{k}_{\mathrm{rv}}-$ koeficijent radnog vremena & 0,84 \\
\hline $\mathrm{k}_{\mathrm{ds}}$ - koeficijent dotrajalosti stroja & 1,00 \\
\hline
\end{tabular}

Uvođenjem svih očitanih vrijednosti iz Tablice 3 u izraz (9), a potom zajedno sa vrijednostima teoretskog učinka u izraz (8), dobiva se vrijednost praktičnog učinka rada bagera, koja u ovom slučaju iznosi $76,07 \mathrm{~m}^{3} / \mathrm{h}$. Odnos praktičnog učinka stroja i njegova normativa rada je recipročan te za promatrani tehnološki postupak standardnog cikličkog građevinskog stroja iznosi $0,0131 \mathrm{~h} / \mathrm{m}^{3}$.

Uzme li se u obzir vrijeme jediničnog radnog ciklusa od 20 sekundi, tada vrijednost praktičnog učinka rada bagera iznosi $95,09 \mathrm{~m}^{3} / \mathrm{h}$, odnosno normativ vremena rada iznosi $0,0105 \mathrm{~h} / \mathrm{m}^{3}$. Navedeni kontrolni proračun pokazuje da odabir vremena jediničnog radnog ciklusa može značajno utjecati na izračun praktičnog učinka tijekom procesa planiranja.

\subsection{Usporedba dobivenih rezultata}

Normativ vremena rada bagera pri utovaru iskopanog materijala $\mathrm{u}$ transportno sredstvo iznosi $0,0184 \mathrm{~h} / \mathrm{m}^{3}$, što predstavlja stvarni tj. mjereni normativ rada na predmetnom gradilištu. Ukoliko se dobiveni rezultat prikaže u obliku učinka, tada mjereni učinak dotičnog bagera iznosi $54,35 \mathrm{~m}^{3} / \mathrm{h}$.

Za razliku od rezultata dobivenih mjerenjem i statističkom obradom, što bi predstavljao trenutak u vremenu kada je građevinski projekt već u fazi izvođenja, praktični učinak koji se računa putem normiranih vrijednosti 
služi za planiranje tog istog projekta. Pritom je za poznate uvjete gradilišta izvršen proračun praktičnog učinka bagera u prethodno definiranom radnom procesu koji iznosi $76,07 \mathrm{~m}^{3} / \mathrm{h}$. Razlika između planiranog $\mathrm{i}$ mjerenog učinka iznosi $21,72 \mathrm{~m}^{3} / \mathrm{h}$. Ukoliko se rezultat dobiven mjerenjem usporedi $\mathrm{s}$ rezultatom praktičnog bagera $\mathrm{s}$ bržim jediničnim radnim ciklusom, tada razlika postaje još veća i iznosi čak $40,74 \mathrm{~m}^{3} / \mathrm{h}$.

Navedena razlika može nastati zbog brojnih okolnosti, od onih vezanih za osobu koja promatra radni proces i provodi mjerenje, do onih vezanih za radni proces tj. strojara i gradilište. Ranijim istraživanjem [8] uočeno je postojanje razlika kod cikličkih građevinskih strojeva odnosno između njihovih učinaka dobivenih proračunom u fazi planiranja od onih dobivenih mjerenjem na terenu. Također, utvrđena je direktna zavisnost učinka bagera pri utovaru s vremenom trajanja ciklusa (za kut okreta ruke bagera od $180^{\circ}$ ). U realnim uvjetima, mogući zastoj u radu može nastati zbog utjecaja materijala, uvjeta rada kao i organizacije rada te su autori [8] identificirali da problem proizlazi iz normiranih vrijednosti koeficijenata vezanih uz organizacijske uvjete. Tijekom terenskih mjerenja radnog procesa „utovar iskopanog materijala bagerom u transportno sredstvo“ metodom kronometraže $[13,14]$, utvrđeno je da je mjerni učinak strojeva veći i do $30 \%$ u odnosu na planirani. Navedeni zaključak je donesen na temelju malog broja izmjerenih radnih operacija (mali uzorak, tj. $\mathrm{n}<31$ ).

Za razliku od prethodno spomenutih istraživanja, gdje su se mjerili različiti radni procesi kod različitih cikličkih građevinskih strojeva koji su se naknadno analizirali, kod ovog provedenog mjerenja mjeren je isključivo jedan radni proces za jedan kut okreta ruke bagera tijekom čitavog vremena provođenja terenskih mjerenja. Takav pristup mjerenju omogućio je osobi koja je promatrala i provodila mjerenje da bude fokusirana na radni proces u cijelosti kao i na pojedinačne radne operacije koje treba izmjeriti. Navedeno je rezultiralo bržim umjeravanjem i većom točnosti provođenja mjerenja, kao i smanjenju mogućnosti nastanka greške kod osobe koja provodi mjerenje.

Dobiveni rezultat ovog istraživanja, $\mathrm{U}_{\mathrm{M}} \leq \mathrm{U}_{\mathrm{P}}$, upućuje na to da uzrok zbog kojeg dolazi do odstupanja između planirane i izmjerene vrijednosti leži u koeficijentima redukcije (redukcijski koeficijent materijala, uvjeta rada i organizacije rada) koji se nalaze u proračunskim tablicama za izračun praktičnog učinka strojnog rada, a koje je potrebno ažurirati. Utvrđivanje točnog mjesta nastanka zastoja koji su prouzrokovali ovakvu razliku zahtijeva niz detaljnih mjerenja identičnog radnog procesa, što u ovom trenutku nije moguće napraviti zbog završetka radova. No, uočena problematika otvara potrebu za sustavnim pristupanjem i nastavkom mjerenja u budućnosti s ciljem utvrđivanja novih vrijednosti koeficijenata 
redukcije i ažuriranja postojećih tablica. Tome bi trebala pripomoći upotreba senzora i bežičnih tehnologija [20], koja će zasigurno doprinijeti poboljšanju točnosti mjerenja strojnog rada na gradilištima, ali i bržem prikupljanju i obradi podataka.

\section{Zaključak}

U ovom radu opisana je metodologija proračuna učinaka standardnog cikličkog građevinskog stroja mjerenjem na terenu metodom kronometraže tijekom faze izvođenja radova te jedna od mogućih metodologija proračuna praktičnih učinaka koja se može primijeniti tijekom faze planiranja građevinskih radova. Istraživanjem je utvrđeno da postoje odstupanja između navedenih vrijednosti, odnosno da postoje odstupanja između normativa rada dobivenog na terenu i onog dobivenog proračunom putem normiranih vrijednosti.

Također, utvrđeno je da mjerenja radnog procesa, provedena na predmetnom gradilištu, daju manji učinak rada nego što se to može dobiti proračunom putem normiranih vrijednosti te da njihov odnos glasi $U_{M}<U_{P}$. uzroci se mogu tražiti u organizaciji rada na gradilištu (napose ljudskom faktoru), provođenju mjerenja kronometražom kao i koeficijentima redukcije iz postojećih normiranih tablica.

Istraživanjem je naglašeno kako razlike između praktičnog učinka (kojim se vrši planiranje radova) i mjerenog učinka (koji se može ustanoviti tijekom izvođenja radova) postoje te je ukazano na potrebu za daljnjim kontinuiranim istraživanjem u području studija rada. Prilog tome je i činjenica da ovakve razlike mogu značajno utjecati na tijek provođenja građevinskog projekta u fazi izgradnje, kao i na ugovoreni rok gradnje. Iako je na „malim gradilištima“, tj. pri malim količinama utovara, razlika u vremenu relativno mala i zanemariva, kod „velikih gradilišta“ ona postaje velika i značajna. Štoviše, pri velikim količinama utovara razlika između planirane i stvarne vrijednosti može utjecati na projekt na takav način da planirano vrijeme izvođenja radova postane neizvedivo.

Preporuča se nastavak proučavanja i mjerenja rada na gradilištima i uvođenje bežičnih tehnologija u procese mjerenja rada s ciljem preciznog utvrđivanja mjesta nastanka zastoja i ažuriranja postojećih proračunskih tablica, što bi dovelo do usklađivanja planiranih vrijednosti sa stvarnima koje je moguće realizirati.

Zahvala. Autori se zahvaljuju tvrtki GPP Mikić d.o.o. iz Omišlja na otoku Krku na stvaranju okruženja za provođenje terenskih mjerenja u sklopu gradilišta KBC Sušak u Rijeci. 


\section{Literatura}

[1] Rukavina, J., Marović, I. (2017) Pregled građevina bespilotnim letjelicama $i$ daljinski upravljanim podmornicama. U: Lakušić, S., ur. Izazovi u graditeljstvu. Zagreb: Hrvatski savez građevinskih inženjera, str. 111-128.

[2] International Federation of Robotics. URL: http://www. ifr.org (23.11.2017.)

[3] Pinter, U., Lončarić, R. (2006) Značaj studija rada u građevinarstvu. Građevinar, 58(10), str. 807-812.

[4] Hrvatska enciklopedija. URL: http://www.enciklopedija.hr (15.12.2017.)

[5] Taboršak, D. (1987) Studij rada. Zagreb: Tehnička knjiga.

[6] Radujković, M. i suradnici (2015) Organizacija građenja. Zagreb: Sveučilište u Zagrebu, Građevinski fakultet.

[7] Klepac, J. (1982) Proučavanje rada u građevinarstvu. Zagreb: Građevinski institut.

[8] Car-Pušić, D., Husić, F., Marović, I. (2008) Analiza učinaka standardne građevinske mehanizacije na izgradnji ceste Vodnjan-Pula. Zbornik radova Građevinskog fakulteta Sveučilišta u Rijeci, Vol. 11, str. 175-188.

[9] Linarić, Z. (2007) Leksikon strojeva i opreme za proizvodnju građevinskih materijala, Učinci za strojeve i vozila pri zemljanim radovima. Zagreb: Business Media Croatia.

[10] Trbojević, B. (1988) Građevinske mašine. Beograd: Građevinska knjiga.

[11] Car-Pušić, D. (2016) Nastavni materijal kolegija Organizacija i tehnologija građenja. Rijeka: Sveučilište u Rijeci, Građevinski fakultet.

[12] Slunjski, E. (1995) Strojevi u građevinarstvu. Zagreb: Hrvatsko društvo građevinskih inženjera.

[13] Marović, I., Car-Pušić, D., Završki, I. (2008) Application of Chronometry Method towards Calculation of Regulation. U: Radujković, M., Mlinarić, V., Izetbegović, J., Cerić, A., ur. Proceedings of 8th International Conference on Organization, Technology and Management in Construction. Zagreb: Croatian Association for Construction Management, str. i1-i8.

[14] Marović, I., Žic, E., Jajac, N. (2011) Application of Snapback Chronometry Method in Calculation of Regulation. Journal of Civil Engineering and Architecture. Vol. 5, broj 3, str. 273-277.

[15] Taylor, F. W. (1947) The Principles of Scientific Management. New York: Harpes \& Brothers.

[16] Izetbegović, J., Žerjav, V. (2009) Organizacija građevinske proizvodnje. Zagreb: Sveučilište u Zagrebu, Građevinski fakultet i Hrvatska udruga za organizaciju građenja.

[17] Berljafa, A. (2017) Tehnologija iskopa u stijeni s mjerenjem i normiranjem rada. Završni rad. Rijeka: Sveučilište u Rijeci, Građevinski fakultet.

[18] Lopez, Y.C. (2005) Modeling for the Estimation of Work Duration and Management of Labor Resources for the Facilities Department at UPMR. Magistarski rad. Mayaguez: Sveučilište Puerto Rico Mayaguez Campus. 
[19] Perišić, L. Linarić, Z. (2006) Metodologije proračuna radnih učinaka bagera. Mineral. Vol. 10, broj 50, str. 16-22.

[20] Šopić, M., Vukomanović, M., Car-Pušić, D. (2017) Planning and Control of Productivity of Construction Machinery through Use of Wireless Technology. U: Cerić, A., Huemann, M., Radujković, M., Vukomanović, M., Završki, I., ur. Proc. of 13th International Conference on Organization, Technology and Management in Construction. Zagreb: Croatian Association for Construction Management and University of Zagreb, Faculty of Civil Engineering, str. 638649. 